\title{
E-LEARNING SEBAGAI SEBUAH INOVASI METODE ACTIVE LEARNING
}

\author{
Marzuqi Agung Prasetya \\ STIKES Muhammadiyah Kudus, Jawa Tengah, Indonesia \\ marzuqiagung@gmail.com
}

\begin{abstract}
Abstrak
Artikel ini bertujuan menelaah tentang pembelajaran elektronik (e-learning) sebagai sebuah inovasi metode pembelajaran active learning. Kajian ini lebih bersifat library research dengan fokus untuk mengetahui bagaimana teknologi informasi (TI) turut serta mendukung proses collaborative learning yang telah mentransformasikan pola belajar "teacher-centered" menjadi "student-centered" dengan menciptakan budaya belajar mandiri. Dalam hal ini pembelajaran berbasis TI difokuskan pada e-learning sebagai sebuah inovasi metode pembelajaran, sehingga terlihat dengan jelas bagaimana e-learning serta aplikasinya dalam pembelajaran. Dari kajian ini dapat diketahui bahwa e-learning adalah pembelajaran jarak jauh yang menggunakan rangkaian elektronik dan dilakukan melalui media internet untuk menyampaikan isi pembelajaran, interaksi atau bimbingan dengan bahan ajar yang sesuai dengan kebutuhan. E-learning merupakan suatu inovasi pembelajaran serta alternatif solusi bagi perkembangan kebutuhan belajar. Banyaknya faktor perubahan di era globalisasi turut serta berfungsi sebagai katalisator untuk revolusi sistem pembelajaran dari yang sebelumnya bersifat manual dan konvensional menjadi suatu sistem yang efektif dan efisien dengan dukungan TI.

Kata kunci: teknologi informasi, inovasi pembelajaran, e-learning dan internet
\end{abstract}




\begin{abstract}
E-LEARNING AS AN INNOVATION OF ACTIVE LEARNING METHOD. This article aims to describe the electronic learning (e-learning) as an innovation of active learning method. This study is library research with the focus to know the role of information technology (IT) in supporting the collaborative learning process which has been transformed the learning pattern of teacher-centered to student-centered by creating an autonomous learning culture. In this case, the learning process based on IT is focused on e-learning as an innovation of learning method, so it is seem clearly how e-learning is and its application in learning process. From this research can be known that e-learning is a long distance learning which uses an electronic connection and it is conducted via electronic media in delivering the learning content, interaction or consultation with the teaching materials that suit the need. E-learning is a learning innovation and also an alternative solution for the developmental learning need. The many of changing factors in globalization era has a role as a catalyst for a revolution from the previous learning system that was manual and conventional into a system that is effective and efficient with an IT support.
\end{abstract}

Keywords: information technology, learning innovation, e-learning and internet

\title{
A. Pendahuluan
}

Teknologi Informasi (TI) telah mengubah paradigma kehidupan manusia. Hampir seluruh aspek kehidupan serta aktivitas manusia dipengaruhi oleh pesan serta TI untuk mendukungnya. E-learning sebagai suatu inovasi pembelajaran serta alternatif solusi bagi perkembangan kebutuhan belajar mendidik dan tenaga kependidikan. Banyaknya faktor perubahan di era globalisasi turut serta berfungsi sebagai katalisator untuk revolusi sistem pembelajaran dari yang sebelumnya bersifat manusla dan konvensional menjadi suatu sistem yang efektif dan efisien dengan dukungan TI.

Sebagaimana diketahui bahwa pembelajaran adalah proses interaksi peserta didik dengan pendidik dan sumber belajar pada suatu lingkungan belajar. Pembelajaran merupakan bantuan yang diberikan pendidik agar dapat terjadi proses perolehan ilmu dan pengetahuan, penguasaan kemahiran dan tabiat, serta pembentukan 
sikap dan kepercayaan pada peserta didik. Dengan kata lain, pembelajaran adalah proses untuk membantu peserta didik agar dapat belajar dengan baik.

Di sisi lain pembelajaran mempunyai pengertian yang mirip dengan pengajaran, tetapi sebenarnya mempunyai konotasi yang berbeda. Dalam konteks pendidikan, guru mengajar agar peserta didik dapat belajar dan menguasai isi pelajaran hingga mencapai sesuatu objektif yang ditentukan (aspek kognitif), juga dapat memengaruhi perubahan sikap (aspek afektif), serta keterampilan (aspek psikomotor) seorang peserta didik, namun proses pengajaran ini memberi kesan hanya sebagai pekerjaan satu pihak, yaitu pekerjaan pengajar saja. Sedangkan pembelajaran menyiratkan adanya interaksi antara pengajar dengan peserta didik.

Pembelajaran yang berkualitas sangat tergantung dari motivasi pelajar dan kreatifitas pengajar. Pelajar yang memiliki motivasi tinggi ditunjang dengan pengajar yang mampu memfasilitasi motivasi tersebut akan membawa pada keberhasilan pencapaian target belajar. Target belajar dapat diukur melalui perubahan sikap dan kemampuan siswa melalui proses belajar. Desain pembelajaran yang baik, ditunjang fasilitas yang memadai, ditambah dengan kreatifitas guru akan membuat peserta didik lebih mudah mencapai target belajar. Dengan demikian dapat dipahami bahwa keberhasilan dari pembelajaran tergantung kepada dua pihak pelaku utama dalam pembelajaran yaitu pendidik dan peserta didik.

Peran aktif siswa yang kurang dalam pembelajaran mengakibatkan pemahaman siswa terhadap suatu materi cenderung lamban dan hasil belajar yang dicapai siswa masih kurang. Tidak bisa dinafikan bahwa pendekatan pendidikan sangat dinamis dalam rangka menghasilkan pembelajaran produktif, demikian pula gaya belajar yang dialami oleh siswa sudah mengalami perubahan akibat kemajuan teknologi dan masyarakat yang maju. Pembelajaran dapat dilakukan oleh siswa tanpa harus bertatap muka dengan pendidik, demikian sebaliknya pendidik dapat melakukan pembelajaran dengan memanfaatkan sumber belajar lainnya yang pada setiap saat dapat diakses tanpa mengenal waktu, lingkungan, dan kondisi. Oleh sebab itu, pembelajaran membutuhkan penggunaan teknologi yang dapat memberikan informasi dengan mudah dan cepat. Penggunaan 
teknologi tersebut di lingkungan pendidikan dikenal dengan e-learning (pembelajaran berbasis komputer).

Tulisan ini akan membahas bagaimana TI turut serta mendukung proses pembelajaran contructivist, yaitu "collaborative learning" yang telah mentransformasikan pola belajar "teachercentered" menjadi " student centered" dengan menciptakan budaya belajar mandiri bagi individu yang belajar. Dalam hal ini pembelajaran berbasis TI difokuskan pada e-learning sebagai sebuah inovasi metode pembelajaran, sehingga akan terlihat dengan jelas bagaimana e-learning serta aplikasinya dalam pembelajaran. E-learning adalah pembelajaran jarak jauh yang menggunakan rangkaian elektronik yang dilakukan melalui media internet untuk menyampaikan isi pembelajaran, interaksi atau bimbingan yang memperoleh bahan belajar sesuai dengan kebutuhanya.

\section{B. Pembahasan}

\section{Konsepsi Pembelajaran}

Dalam memaknai konsep tentang pembelajaran akan berhubungan erat dengan teori. Sebaliknya teori akan berkaitan erat dengan suatu hal yang dipandang secara ilmiah. Pembelajaran merupakan suatu proses, dimana di dalamnya terdapat kegiatan mengajar dan belajar yang dilakukan oleh pendidik dan peserta didik. Mengajar merupakan aktifitas yang dilaksanakan oleh pendidik (guru) yakni menyampaikan materi pembelajaran kepada peserta didik dengan menggunakan metode tertentu. Menurut Majid (2013: 232) bahwa kemampuan guru dalam mengajar terkait juga dengan kemampuannya mengelola pembelajaran yang terkait dengan sejauhmana kemampuan guru (pendidik) dalam menerapkan berbagai variasi, metode maupun model pembelajaran.

Adapun belajar adalah proses perubahan perilaku secara aktif, proses mereaksi terhadap semua situasi yang ada di sekitar individu, proses yang diarahkan pada suatu tujuan, proses berbuat melalui berbagai pengalaman, proses melihat, mengamati, dan memahami sesuatu yang dipelajari. Dalam kegiatan belajar, perubahan yang dimaksudkan merupakan perubahan yang sesuai dengan perubahan yang bersentuhan dengan aspek kejiwaan dan mempengaruhi tingkah laku (Djamarah: 2002: 14). 
Pembelajaran (instruction) merupakan akumulasi dari konsep mengajar (teaching) dan belajar (learning). Penekanannya terletak pada perpaduan antara keduanya, yakni kepada penumbuhan aktivitas subyek didik baik pendidik maupun peserta didik. Konsep tersebut dapat dipandang sebagai suatu sistem, sehingga dalam sistem belajar ini terdapat komponen-komponen:

\section{a. Pendidik}

Pendidik atau guru merupakan orang yang memberikan materi pembelajaran, baik berupa ilmu pengetahuan, maupun nilainilai (value) yang aka berguna bagi kehidupan peserta didik, baik dalam proses pendidikannya maupun dalam praktis kehidupan. Dalam pelaksanaan pembelajaran guru harus berperan ganda, dalam arti guru tidak hanya sebagai pengajar (informatory) saja, akan tetapi harus mampu menjadi programmer pembelajaran, motivator belajar, fasilitator pembelajaran, organisator, konduktor, aktor, dan peranperan lain yang dibutuhkan oleh siswa dalam pembelajaran.

Meskipun guru bukan satu-satunya sumber belajar, tetapi tugas, peranan dan fungsi guru dalam pembelajaran sangatlah penting dan berperan sentral. Karena gurulah yang harus menyiapkan program pembelajaran, bahan pembelajaran, sarana pembelajaran dan evaluasi pembelajaran bagi para siswanya. Maka guru memiliki peran yang sangat menentukan dalam pembelajaran, sehingga keberhasilannya banyak dipengaruhi oleh kesiapan serta kemampuan guru.

\section{b. Peserta didik}

Peserta didik merupakan orang yang belum dewasa, yang mengikuti pembelajaran di kelas dalam rangkan menuju kedewasaan, sehingga membutuhkan arahan maupun bimbingan orang dewasa di sekitarnya. Dalam hal ini peserta didik merupakan bagian dari subyek pembelajaran, sehingga keberadaannya akan berpengaruh terhadap keberlangsungan dari pembelajaran yang diselenggarakan.

Peserta didik, sebagai bagian dari komponen pembelajaran berasal dari jenis kelamin, maupun latar belakang yang berbeda sehingga dibutuhkan pendekatan yang dapat mengakomodir perbedaan tersebut. Lebih lanjut perlu dipahami bahwa perbedaan tersebut dapat berupa perbedaan psikologis, sosial, maupun berasal dari latar belakang bidaya yang berbeda. Peserta didik merupakan 
komponen pembelajaran yang terpenting, karena komponen siswa sebagai pelaku belajar dalam proses pembelajaran. Aspek penting dari komponen peserta didik yang harus diperhatikan dalam pembelajaran adalah karakteristiknya. Peserta didik (siswa) adalah individu yang unik dan memiliki sifat individu yang berbeda antara peserta didik satu dengan yang lain. Dalam satu kelas tidak ada peserta didik yang memiliki karakteristik sama persis, baik kecerdasan, emosi, kebiasaan belajar, kecepatan belajar, dan sebagainya.

\section{c. Tujuan}

Semua aktivitas memiliki suatu tujuan, termasuk aktivitas pembelajaran. Pembelajaran sebagai suatu aktivitas memiliki tujuan yang pasti. Tujuan pembelajaran berperan sebagai arah dan target pencapaian dari suatu kegiatan pembelajaran. Rumusan tujuan pembelajaran memuat kompetensi yang harus dikuasai siswa setelah mengikuti pembelajaran, baik kompetensi kognitif, afektif dan psikomotorik. Tujuan pembelajaran merupakan komponen utama yang harus terlebih dahulu dirumuskan sebelum menentukan komponen pembelajaran yang lain. Tujuan pembelajaran sebagai sasaran dari aktivitas pembelajaran rumusannya memuat rumusan tentang tingkah laku baik yang berkaitan dengan pengetahuan, keterampilan, nilai dan sikap siswa yang hendak dibentuk melalui proses pembelajaran. Secara hirarkhi tujuan pembelajaran dijabarkan dari tujuan pendidikan yang lebih umum ke tujuan yang lebih khusus.

Tujuan pembelajaran menurut taxonomi bloom adalah adanya perubahan baik pada ranah kognisi, afeksi maupun psikomotor. Sehingga perubahan kemampuan yang diharapkan domiliki oleh peserta didik adalah pada aspek pengetahuan, sikap maupun tingkah laku. Idealnya dalam pelaksanaan pembelajaran, tujuan menjadi kerangka acuan dalam pembelajaran, sehingga dalam prosesnya memiliki acuan yang tepat.

\section{d. Materi}

Materi adalah seperangkat bahan ajar yang akan disampaikan oleh pendidik kepada peserta didik. Dalam hal ini materi pembelajaran yang diberikan diharapkan akan berdampak pada peserta didik dan mengarah pada perubahan yang meliputi aspek kognitif, afektif maupun psikomotor. Di samping itu materi dapat 
berupa kajian teoritis maupun praktis, sehingga akan memberikan bekal bagi peserta didik dalam berkehidupan bermasyarakat.

Materi pelajaran merupakan komponen isi pesan dalam kurikulum yang harus disampaikan kepada peserta didik. Komponen ini memiliki bentuk pesan yang beragam, ada yang berbentuk fakta, konsep, prinsip/kaidah, prosedur, problema, dan sebagainya. Komponen ini berperan sebagai isi atau materi yang harus dikuasai siswa dalam proses pembelajaran. Skop dan sekuen materi pelajaran telah tersusun secara sistematis dalam struktur organisasi kurikulum sekolah.

Setiap pembelajaran akan dilaksanakan, hendaknya guru memahami karakteristik isi pesan pembelajaran yang akan disampaikan, agar tidak salah dalam memilih strategi pembelajarannya, interaksi pembelajaran, pengelolaan kelas, pemilihan bahan pembelajaran dan media pembelajaran, serta alat evaluasinya. Sehingga materi yang disampaikan dapat mendukung keberhasilan pembelajaran yang dilaksanakan.

\section{e. Metode}

Metode merupakan cara yang ditempuh oleh guru untuk menyampaikan materi pembelajaran kepada peserta didik (siswa), sehingga dalam hal ini metode pembelajaran dapat dikelompokkan dalam tiga kelompok, yaitu kelompok metode yang bersifat monologis, dialogis dan kreatif. Kelompok pertama adalah metode-metode yang bersifat monologis, yaitu metode-metode pembelajaran yang lebih menekankan aktivitas guru dalam pembelajaran atau metode satu arah (one way communication), dan guru pemegang peranan utama, sedangkan siswa bersifat pasif (mendengar dan memperhatikan). Kelompok kedua adalah metode-metode yang bersifat dialogis, yaitu metode-metode pembelajaran yang menekankan komunikasi/ interaksi dua arah (two way communications), di mana aktivitas guru dan siswa seimbang (sama-sama aktif). Sedang kelompok ketiga adalah metode-metode yang bersifat kreatif, yaitu metodemetode pembelajaran yang lebih menekankan aktivitas siswa. Metode-metode kelompok ketiga ini dimaksudkan agar sifat kreatif siswa terbentuk, sementara guru berperan sebagai fasilitator dan organisator pembelajaran. 


\section{f. Media}

Media pembelajaran merupakan sarana atau alat yang digunakan dan mendukung proses pembelajaran, sehingga media sebagai alat bantu keberadaannya turut mempengaruhi pelaksanaan pembelajaran. Media dapat berbentuk audio, visual maupun audiovisual.

Dalam pembelajaran jarak jauh, media pembelajaran dapat diwujudkan dalam bentuk bahan pembelajaran yang dipersiapkan/ didesain untukbelajar mandiri,seperti:modul (bahan ajar cetak), radio/ audio pembelajaran, televisi pembelajaran, $\mathrm{CD} /$ video pembelajaran, dan e-learning lewat web-based/internet. Khusus media sebagai bahan pembelajaran, dapat diklasifikasikan menjadi dua kelompok yaitu bahan pembelajaran yang didesain dengan tidak menggunakan komponen pembelajaran lengkap dan dengan menggunakan komponen pembelajaran lengkap. Menurut Edgar Dale dalam Kerucut Pengalaman (the cone of experience)-nya mengklasifikasikan media pembelajaran dalam beberapa macam, dari yang paling konkrit sampai yang paling abstrak.

Sebagaimana diketahui, mengajar adalah membimbing kegiatan belajar peserta didik sehingga ia mau mengajar. Dengan demikian, Aktivitas murid sangat diperlukan dalam kegiatan belajar mengajar sehingga muridlah yang seharusnya banyak aktif, sebab murid sebagai subyek didik adalah yang merencanakan dan ia sendiri yang melaksanakan belajar (Daryanto, 2013: 191).

Dalam UU No. 20/2003, Bab I Pasal Ayat 20 pembelajaran adalah proses interaksi peserta didik dengan pendidik dan sumber belajar pada suatu lingkungan belajar. Menurut penulis istilah pembelajaran dapat dimaknai sebagai usaha sadar dari guru untuk membuat siswa belajar, yaitu terjadinya perubahan tingkah laku pada diri siswa yang belajar, dimana perubahan itu dengan didapatkannya kemampuan baru yang berlaku dalam waktu yang relatif lama dan karena adanya usaha.

Dalam paradigma lama, kegiatan pembelajaran biasanya didominasi oleh pendidik sehingga lebih teacher oriented atau pemebelajaran berpusat pada guru, maka dalam pembelajaran pada masa sekarang paradigma pembelajaran lebih dinamis karena berbasis student oriented atau pembelajaran berorientasi pada peserta 
didik/siswa. Sehingga pembelajaran dengan sistem ini dua pihak yang terlibat dalam pembelajaran sama-sama aktif.

Pembelajaran merupakan bentuk interaksi antara pendidik dengan peserta didik. Dalam perkembangannya, pembelajaran bukan hanya bentuk interaksi pendidik dan peserta didik saja, namun juga dengan sumber-sumber belajar. Hal ini dapat diartikan bahwa pembelajaran merupakan sebuah sistem yang saling terkait satu dengan yang lainnya. Pembelajaran sebagai sebuah sistem terdiri dari komponen-komponen yang saling berinteraksi, berinterelasi, dan berinterdependensi antara satu dengan yang lainnya untuk mencapai tujuan pembelajaran yang telah ditetapkan. Komponen tersebut antara lain tujuan, pendidik, peserta didik, kurikulum, strategi, media, dan evaluasi.

Dalam proses pembelajaran, beberapa komponen tersebut turut mempengaruhi keberhasilan pembelajaran, sehingga masingmasing komponen tersebut sangat penting keberadaannya dalam prmbelajaran, serta tidak dapat dipastikan komponen mana yang paling dominan mempengaruhi pembelajaran.

\section{Macam-macam Metode Pembelajaran}

Pendidik memiliki peran yang sangat penting dalam menentukan kualitas dan kuantitas pengajaran yang dilaksanakannya. Oleh karena itu, pendidik harus memikirkan dan membuat perencanaan secara seksama dalam meningkatkan kesempatan belajar bagi peserta didiknya dan memperbaiki kualitas mengajarnya. Hal ini menuntut perubahan-perubahan dalam mengajarnya baik dalam hal penggunaan metode mengajar, strategi mengajar, maupun sikap dan karakteristik pendidik selaku pengelola belajar mengajar, bertindak selaku fasilitator yang berusaha menciptakan kondisi belajar mengajar, mengembangkan bahan pelajaran dengan baik, meningkatkan kemampuan peserta didik untuk menyimak pelajaran, dan menguasai tujuan-tujuan pendidikan yang harus dicapai.

Dalam pembelajaran terdapat beberapa komponen yaitu; pendidik, peserta didik, materi, metode, media dan tujuan pembelajaran. Adapun metode-metode pembelajaran diantaranya adalah sebagai berikut: 


\section{a. Metode pembelajaran ceramah}

Adalah penerangan secara lisan atas bahan pembelajaran kepada sekelompok pendengar untuk mencapai tujuan pembelajaran tertentu dalam jumlah yang relatif besar. Dengan metode ceramah, guru dapat mendorong timbulnya inspirasi bagi pendengarnya. Ceramah cocok untuk penyampaian bahan belajar yang berupa informasi dan jika bahan belajar tersebut sukar didapatkan.

\section{b. Metode Diskusi}

Metode pembelajaran diskusi adalah proses pelibatan dua orang peserta atau lebih untuk berinteraksi saling bertukar pendapat, dan atau saling mempertahankan pendapat dalam pemecahan masalah sehingga didapatkan kesepakatan diantara mereka. Pembelajaran yang menggunakan metode diskusi merupakan pembelajaran yang bersifat interaktif.

\section{c. Metode Tanya Jawab}

Metode tanya jawab merupakan metode pembelajaran, dimana peserta didik mengajukan kepada pendidik dan sebaliknya pendidik mengajukan pertanyaan kepada peserta didik. Dalam metode pembelajaran ini, antara pendidik dan peserta didik samasama aktif, sehingga komunikasi pembelajaran menjadi hidup.

\section{d. Metode Tugas dan Resitasi}

Secara harfiah, resitasi merupakan pembacaan hafalan di muka umum atau hafalan yang diucapkan oleh murid-murid di dalam kelas (Supriadie, 2012: 23) sementara dalam kamus besar bahasa Indonesia tertulis bahwa resitasi sebagai metode belajar yang mengkombinasikan penghafalan, pembacaan, pengulangan, pengujian dan pemeriksaan diri sendiri.

Metode tugas dan resitasi tidak sama dengan pekerjaan rumah, tetapi lebih luas dari itu. Tugas dan resitasi merangsang anak untuk aktif belajar baik secara individu maupun kelompok. Tugas dan resitasi dapat dilakukan di rumah, sekolah, perpustakaan dan tempat lainnya (Majid, 2013: 208).

Jadi, metode resitasi merupakan metode dimana pendidik memberi tugas kepada peserta didik untuk mengerjakan tugas tertentu dalam pembelajaran, tugas ini dapat dilaksanakan di ruang belajar (kelas) maupun penugasan yang harus dikerjakan di rumah 
(PR). Disamping itu dalam penugasan ini dapat berupa tugas mandiri maupun tugas terbimbing, yaitu pendidik memberikan tugas kepada peserta didik dengan dibimbing oleh pendidik.

\section{e. Metode Latihan (drill)}

Metode latihan pada umumnya digunakan untuk memperoleh suatu ketangkasan atau ketrampilan dari apa yang telah dipelajari. Drill merupakan suatu tindakan untuk meningkatkan kemahiran dan ketrampilan. Sebagai sebuah metode, drill adalah cara membelajarkan siswa untuk mengembangkan kemahiran dan ketrampilan serta dapat mengembangkan sikap dan kebiasaan. Latihan merupakan proses belajar dan membiasakan diri agar mampu melakukan sesuatu.

\section{f. Metode Eksperimen}

Metode pembelajaran eksperimental adalah suatu cara pengelolaan pembelajaran di mana siswa melakukan aktivitas percobaan dengan mengalami dan membuktikan sendiri sesuatu yang dipelajarinya. Dalam metode ini peserta didik diberi kesempatan untuk mengalami sendiri atau melakukan sendiri dengan mengikuti suatu proses, mengamati suatu obyek, menganalisis, membuktikan dan menarik kesimpulan sendiri tentang obyek yang dipelajarinya.

\section{g. Metode Karya Wisata (field-trip)}

Metode karya wisata merupakan metode pembelajaran dengan berwisata atau mengunjungi tempat-tempat bersejarah yang ada korelasinya dengan materi pembelajaran, metode karyawisata sangat relevan digunakan adalam pembelajaran yang bermuatan sejarah, sehingga peserta didik memperoleh gambaran dengan jelas, tentang materi pembelajaran yang sedang dipelajarinya. Karya wisata di sini artinya adalah kunjungan ke luar kelas dalam rangka belajar. Jadi, karya wisata tersebut tidak mengambil lokasi yang jauh dari sekolah serta tidak memerlukan waktu yang lama.

\section{h. Metode Psikodrama}

Psikodrama merupakan metode pembelajaran dengan bermain peran yang bertitik tolak dari permasalahan-permasalahan psikologis. Psikodrama biasanya digunakan untuk terapi, yaitu agar siswa memperoleh pemahaman yang lebih baik tentang dirinya, menemukan konseo diri, menyatakan reaksi terhadap tekanantekanan yang dialaminya (Majid, 2013: 206). 


\section{i. Metode Sosio Drama}

Sosiodrama merupakan metode pembelajaran dengan bermain peran yang bertitik tolak dari permasalahan-permasalahan dan fenomena sosial, permasalahan yang menyangkut hubungan antara manusia seperti permasalahan kenakalan remaja, narkoba, gambaran keluarga yang otoriter dan lain sebagainya. Sosiodrama digunakan untuk memberikan pemahaman dan penghayatan akan masalah-masalah sosial serta mengembangkan kemampuan siswa untuk memecahkannya.

\section{j. Metode Demonstrasi}

Metode demonstrasi adalah petunjuk tentang proses terjadinya suatu peristiwa atau benda sampai pada penampilan tingkah laku yang dicontohkan agar dapat diketahui dan dipahami oleh peserta didik.

Jadi, metode demonstrasi merupakan metode dengan cara mempertunjukkan atau mempertontonkan sesuatu dapat berupa perilaku yang diperlihatkan kepada peserta didik, sehingga perilaku yang menjadi materi pembelajaran dapat lebih mudah dipahami oleh peserta didik. Metode demonstrasi dapat digunakan untuk materi pembelajaran yang bertujuan agar peserta didik dapat menirukan contoh perilaku yang didemonstrasikan oleh pendidik. Contoh materi pembelajar fiqh pada pokok bahasan shalat.

\section{E-learning sebagai Inovasi Metode Pembelajaran Active Learning}

Inovasi sistem pembelajaran tidak akan pernah terhenti karena berbagai kebutuhan manusia untuk belajar semakin meningkat. Perkembangan Teknologi Informasi (TI) yang sangat cepat dalam dasa warna terakhir ini menampakkan tanda-tanda adanya revolusi informasi. Berkembangnya internet sebagai salah satu temuan terpenting abad ini telah menyebabkan konvergensi macammacam perkembangan teknologi di atas dalam usaha menghasilkan informasi, kapanpun, dimanapun dan dengan apapun peralatan yang digunakan.

Dalam hal ini active learning menjadi sebuah alternatif dalam pembelajaran. Sebagaimana diketahui bahwa active learning atau pembelajaran aktif merupakan suatu kegiatan pembelajaran 
dimana terdapat keterlibatan pelajar dalam melakukan kegiatan dan memikirkan apa yang sedang dilakukan. Pembelajaran aktif secara tidak langsung menganjurkan untuk menciptakan inovasi dalam proses pembelajaran supaya lebih menyenangkan dan mudah diterima. Hal ini harus diperhatikan mengingat cara belajar dan memahami setiap orang berbeda, namun dalam belajar aktif, menjadikan pesrta didik harus aktif untuk menggali pengetahuan.

Salah satu metode pembelajaran active learning yang dapat digunakan adalah dengan e-learning. Secara harfiah e-learning merupakan akronim dari E \& Learning. E bermakna electric dan learning berarti proses. Jadi, e-learning adalah sistem pembelajaran secara electronik, menggunakan media elektronik, internet, komputer, dan file media (suara, gambar, animasi dan video).

E-pembelajaran atau pembelajaran elektronik pertama kali diperkenalkan oleh universitas Illinois di Urbana-Champaign dengan menggunakan sistem instruksi berbasis komputer (computerassisted instruction) dan komputer bernama PLATO. Sejak itu, perkembangan E-learning dari masa ke masa adalah sebagai berikut: (1) Tahun 1990: Era CBT (Computer-Based Training) di mana mulai bermunculan aplikasi e-learning yang berjalan dalam PC standlone ataupun berbentuk kemasan CD-ROM. Isi materi dalam bentuk tulisan maupun multimedia (Video dan AUDIO) dalam format mov, mpeg-1, atau avi. (2) Tahun 1994: Seiring dengan diterimanya CBT oleh masyarakat sejak tahun 1994 CBT muncul dalam bentuk paketpaket yang lebih menarik dan diproduksi secara massal.

\section{a. Karakteristik E-learning}

Menurut Daryanto (2013: 31), karakteristik e-learning adalah sebagai berikut:

1) Ada keterpisahan yang mendekati secara permanen antara tenaga pengajar (guru atau dosen) dari peserta ajar (peserta didik atau maha peserta didik (mahasiswa untuk tingkatan perguruan tinggi) selama program pendidikan.

2) Ada keterpisahan yang mendekati permanen antara seorang peserta didik dari peserta didik yang lain selama program pendidikan.

3) Ada suatu institusi yang mengelola program pendidikannya.

4) Pemanfaatan sarana komunikasi baik mekanis maupun elektronis untuk menyampaikan bahan ajar. 
5) Penyediaan sarana komunikasi dua arah sehingga peserta didik dapat mengambil inisiatif dialog dan mengambil manfaatnya.

E-learning dengan demikian merupakan proses pembelajaran secara elektronik. Artinya, elektronik bukan semata-mata peralatannya, melainkan metode dan medianya, bagaimana kita berbagi ilmu pengetahuan, men-download materi pembelajaran, meng-upload tugas, melakukan diskusi dengan dosen maupun kegiatan pembelajaran yang lain dilakukan secara elektronik.

Berdasarkan hal tersebut, maka pembelajaran e-learning antara pendidik dengan peserta didik tidak harus bertatap muka (face to face) tetapi pertemuan keduanya terwakili dengan kehadiran media internet tersebut. Menurut penulis pembelajaran E-learning dapat disebut sebagai pembelajaran jarak jauh. Sebagaimana diketahui bahwa pembelajaran jarak jauh (juga disebut pendidikan jarak jauh) merupakan pelatihan yang diberikan kepada peserta atau siswa yang tidak berkumpul bersama di satu tempat secara rutin untuk menerima pelajaran secara langsung dari instruktur. Bahan-bahan dan instruksi-instruksi detail yang bersifat khusus dikirimkan atau disediakan untuk para peserta yang selanjutnya melaksanakan tugastugas yang akan dievaluasi oleh instruktur. Dalam kenyataannya dapat dimungkinkan instruktur dan peserta tersebut terpisah tidak hanya secara geografis namun juga waktu.

E-learning merupakan metode penyampaian materi pembelajaran dengan komputer dan memanfaatkan teknologi internet serta pemrograman yang memungkinkan para peserta didik untuk berinteraksi dengan bahan-bahan pelajaran melalui chat room (ruang komunikasi), notice board (papan pengumuman), video conferencing, dan lain sebagainya.

Dalam hal ini perlu menjadi pertimbangan bahwa pembelajaran jarak jauh memerlukan suatu pendekatan yang berbeda dalam hal perencanaan, perancangan, penyampaian kursus dan komunikasi. Peserta membutuhkan motivasi diri untuk memulai dan mengembangkan persistensi dan keahlian-keahlian dalam tugas yang bersifat mandiri (self-directing work). Instruktur akan mengembangkan dan menggunakan metodologi-metodologi dan gaya-gaya pembelajaran baru, mulai dari instruksi langsung hingga mengelola strategi-strategi pembelajaran, memberi dukungan 
terhadap peserta didik, memfasilitasi perdebatan jarak jauh, serta mendiseminasi informasi dan pandangan-pandangan.

Menurut Nursalam (2008: 135) karakteristik e-learning adalah sebagai berikut:

1) Memanfaatkan jasa teknologi elektronik.

2) Memanfaatkan keunggulan komputer (digital media dan komputer networks)

3) Menggunakan bahan ajar yang bersifat mandiri (selflearning materials) kemudian disimpan di komputer, sehingga dapat diakses oleh dosen dan mahasiswa kapan saja dan dimana saja.

4) Memanfaatkan jadwal pembelajaran, kurikulum, hasil kemajuan belajar, dan hal-hal yang berkaitan dengan administrasi pendidikan dapat dilihat setiap saat di komputer.

\section{b. Strategi dan Aplikasi Pembelajaran E-learning}

Sebagaimana diketahui bahwa perkembangan teknologi seperti pisau bermata dua, yaitu yang satu dapat memberikan kebaikan dan membantu, tetapi di sisi lain dapat menjadi ancaman atau kekurangan jika tidak digunakan secara tepat. Namun harus diakui bahwa TI memang memberikan dampak positif terutama pada sistem pembelajaran, sehingga transformasi pengetahuan dan informasi tidak tergantung pada tempat dan waktu, dapat belajar sepanjang hidup, dan materi lebih berbasis pada kasus, skill, kebutuhan pasar, dan lain-lain.

Ada beberapa langkah penyusunan program pembelajaran berbasis komputer dengan metode e-learning yaitu:

1) Perencanaan Awal

a) Mendigendifikasi tujuan, kebutuhan, dan masalah yang muncul dalam pembelajaran

b) Analisis karakteristik peserta didik yang akan menggunakan dan mempelajari materi yang akan dikembangkan

c) Mempertimbangkan strategi pembelajaran

2) Menyiapkan Materi

a) Menguasai materi dan metodologi pembelajaran

b) Menguasai ptosedur pengembangan media

c) Menguasai teknik pemrograman komputer

d) Mengetahui keterbatasan komputer

3) Mendesain Paket Program Pembelajaran 
Paket program pembelajaran harus mampu memperkenalkan materi baru untuk melengkapi atau menguatkan pelajaran yang telah berlangsung dengan media lain

4) Memvalidasi Paket Program Pembelajaran

Memvalidasi paket program artinya menguji secara empiris lewat ujian lapangan pada paket program yang dikembangkan. Paket program diujicobakan dengan memilih sampel yang represntatif. Program pembelajaran perlu memperhatikan hal-hal sebagai berikut:
a) Kebenaran bahan ajar
b) Ketepatan antara program dengan populasi pengguna
c) Kesederhanaan program
d) Efisiensi penggunaannya
e) Reliabilitas (Daryanto, 2013:34).

\section{c. Kelebihan E-learning}

Sebagaimana metode pembelajaran yang lain, dalam metode e-learning juga memiliki kelebihan dan kekurangan. Adapun kelebihan dari metode pembelajaran e-learning diantaranya adalah:

1) Mengoptimalkan kualitas belajar

2) Menghemat waktu proses belajar mengajar

3) User friendly, bebas dari kerepotan dan keruwetan

4) Cara belajar yang aman dan sehat

5) Melatih peserta didik lebih mandiri dan berkembang dalam ilmu dan pengetahuan

6) Bebas dari penggunaan kertas

7) Dapat diakses dimanapun dan kapanpun waktunya, sehingga waktunya lebih fleksibel

Pada sisi lain, metode pembelajaran e-learning juga dapat menciptakan kondisi tertentu yang mampu menciptakan hal-hal positif; menumbuhkan kesadaran akan pentingnya ilmu pengetahuan dan teknologi, mendorong kreatifitas pendidik maupun peserta didik, mendorong kemandirian peserta didik, serta mendorong peserta didik berpikir kritis.

Sebagaimana diketahui bahwa e-learning dapat dimasukkan sebagai model pembelajaran jarak jauh, karena belajar dapat dilaksanakan di rumah, tempat kerja, maupun sekolah dengan 
jaringan khusus seperti; internet, intranet maupun alat teknologi digital. Pada prinsipnya e-learning menyediakan cara belajar yang cepat, hemat cost (biaya), serta meningkatkan akses belajar dan akuntabilitas jelas untuk semua partisipan dalam pembelajaran. Jadi, e-learning merupakan jaringan yang mempunyai kemampuan melakukan perubahan dengan cepat, penyimpanan kembali, pendistribusian, serta membagi informasi atau instruksi.

Perlu dipahami bahwa dalam pembelajaran berbasis web ada beberapa hal yang perlu dikembangkan diantaranya; menyiapkan bahan yang sudah ada, menyiapkan kuis, menyiapkan kelas, dan mailing lists, membuat dan menscanner gambar, digitalisasi video maupun mengembangkan file audio.

Dalam prakteknya e-learning memerlukan bantuan teknologi. Karena itu dikenal istilah Computer Basic Learning $(C B L)$ yaitu pembelajaran yang sepenuhnya mengunakan alat bantu utama computer. Sehingga pembelajaran E-Learning ini merupakan pembelajaran yang berbasis Teknologi Informasi (TI), yang mengharuskan pendidik maupun peserta didik sama-sama mengetahui, mengenal dan faham internet serta perangkat TI yang lain. Disamping itu pembelajaran ini akan memacu peserta didik untuk aktif dan kreatif dalam mengikuti pembelajaran.

Pembelajaran berbasis elektronik akan menciptakan suasanapembelajaran yang efektif, efisien, dan meningkatkan mutu pendidikan. Akan tetapi, e-learning bukanlah tujuan pembelajaran itu sendiri sehingga kemudahan yang terdapat di dalamnya jangan melupakan esensi utamanya. Tujuan utama untuk keberhasilan kualitas pembelajaran dipengaruhi oleh materi pembelajaran itu sendiri. E-learning merupakan salah satu media yang digunakan untuk menunjang kesuksesan pembelajaran.

E-learning akan membentuk kebiasaan siswa untuk belajar mandiri, keterampilan berkomunikasi (comunication skill), kemampuan bernalar, dan bersosialisasi. Selain itu, siswa akan mampu melakukan komunikasi dengan baik secara lisan maupun tertulis dengan orang lain. Tindakan yangdilakukan ialah berburu berbagai macam referensi sumber pembelajaran yang dapat di-download dan dipelajari secara mandiri oleh siswa sehingga kemandirian belajar akan tercipta dengan sendirinya. 


\section{Simpulan}

Pembelajaran mempunyai pengertian yang mirip dengan pengajaran, tetapi sebenarnya mempunyai konotasi yang berbeda. Dalam konteks pendidikan, guru mengajar agar peserta didik dapat belajar dan menguasai isi pelajaran hingga mencapai sesuatu objektif yang ditentukan (aspek kognitif), juga dapat memengaruhi perubahan sikap (aspek afektif), serta keterampilan (aspek psikomotor) seorang peserta didik, namun proses pengajaran ini memberi kesan hanya sebagai pekerjaan satu pihak, yaitu pekerjaan pengajar saja. Sedangkan pembelajaran menyiratkan adanya interaksi antara pengajar dengan peserta didik.

Teknologi Informasi (TI) telah mengubah paradigma kehidupan manusia. Hampir seluruh aspek kehidupan serta aktivitas manusia dipengaruhi oleh pesan serta TI untuk mendukungnya. E-learning sebagai suatu inovasi pembelajaran serta alternatif solusi bagi perkembangan kebutuhan belajar mendidik dan tenaga kependidikan. Banyaknya faktor perubahan di era globalisasi turut serta berfungsi sebagai katalisator untuk revolusi sistem pembelajaran dari yang sebelumnya bersifat manusla dan konvensional menjadi suatu sistem yang efektif dan efisien dengan dukungan TI.

E-learning dengan demikian merupakan proses pembelajaran secara elektronik. Artinya, elektronik bukan semata-mata perelatannya, melainkan metode dan medianya, bagaimana kita berbagi ilmu pengetahuan, men-download materi pembelajaran, mengupload tugas, melakukan diskusi dengan dosen maupun kegiatan pembelajaran yang lain dilakukan secara elektronik. Jadi, pembelajaran e-learning antara pendidik dengan peserta didik tidak harus bertatap muka (face to face) tetapi pertemuan keduanya terwakili dengan kehadiran media internet tersebut. 
Arsyad, Azhar. 2011. Media Pembelajaran. Jakarta: Rajawali Pers.

Daryanto. 2013. Inovasi Pembelajaran Efektif. Bandung: Yrama Widya.

Dick, W., Carey, L., \& Carey, J.O. 2003. The Systemic Design of Instruction. New York : Harper Collins Publisher Inc.

Djamarah, Syaiful Bahri. 2002. Psikologi Belajar. Jakarta: Rineka Cipta.

Hermawan, A.H dkk. 2008. Pengembangan Kurikulum dan Pembelajaran. Jakarta: Universitas Terbuka.

Himpunan Peraturan Perundang-undangan. 2009. Undang-undang Sisdiknas Nomor 20 Tahun 2003. Bandung: Fokus Media.

Mulyasa. 2013. Pengembangan dan Implementasi Kurikulum 2013. Bandung: Remaja Rosdakarya.

Peraturan Menteri No. 41 tahun 2007 tentang Standar Proses

Purbo, Onno W. 2003. E-Learning dan Pendidikan, Artikel dalam Cakrawala Pendidikan Universitas Terbuka.

Simamora, Lamhot S.P. 2003. E-Learning: Konsep dan Perkembangan teknologi Yang Mendukungnya. Artikel dalam Cakrawala Pendidikan Universitas Terbuka.

Soekamto, Toeti. 1997. Teori Belajar dan Model-model Pembelajaran. Jakarta: Pusat Antar Universitas untuk Peningkatan dan Pengembangan Aktivitas Instruksional Direktorat Jendral Pendidikan Tinggi DepDikBud.

Sujarwo. 2012. Model-model Pembelajaran: Suatu Strategi Mengajar. Yogyakarta: t.p. 
Marzuqi Agung Prasetya

halaman ini bukan sengaja dikosongkan 